\title{
Study of Everyday Language Practices of the Population of South Russian Multinational Region
}

\author{
Valentina Ivashova \\ Candidate of Social Sciences, Docent, \\ Docent of Project Management Department of Stavropol \\ State Agrarian University, \\ Stavropol, Russia \\ Olga Chudnova \\ Candidate of Psychological Sciences, Docent, \\ Docent of Foreign Languages Department of Stavropol \\ State Agrarian University, \\ Stavropol, Russia
}

\author{
Irina Makhova \\ Candidate of Philological Sciences, Docent, \\ Docent of Foreign Languages Department of Stavropol \\ State Agrarian University, \\ Stavropol, Russia \\ Valentina Rodionova \\ Doctor of Philosophical Sciences, Professor, \\ Department of Social and Humanitarian Disciplines, \\ Don State Technical University (Branch), \\ Shakhty, Russia
}

\author{
Lyudmila Shvachkina \\ Doctor of Philosophical Sciences, Professor, \\ Department of Social and Humanitarian Disciplines, Don State Technical University (Branch), \\ Shakhty, Russia.
}

\begin{abstract}
The article presents the results of a sociological study "National and Cultural Identity of the Population of the Stavropol Region", conducted in 14 municipal and urban districts of the Stavropol Region in 2019. The results of the survey of 1147 respondents aged 18 to 65 made it possible to characterize the regional community of the strategically important territory of southern Russia in terms of nationalcultural self-determination and self-identification and to determine the role of everyday language practices in this process. Segmentation of the survey participants by sex, age, level of education, and the type of community in which the respondents live, allows one to expand understanding of the practical use of bilingual language practices in selected social groups. The results of the study of everyday language practices of various social groups of the population of southern Russia are important for determining the vectors of the national cultural and social policies of the region and promising areas of education, culture, youth organizations of the Stavropol Region and of southern Russia in general.
\end{abstract}

Keywords - Bilingualism, regional community, everyday language practice, social groups, national-cultural identification, language communication

\section{INTRODUCTION}

The North Caucasus, as the southern region of Russia, and the Stavropol Region is also characterized by the historically established multinational composition of the population. So, for example, in the Stavropol Region (according to statistical studies) live about 120 nationalities. Most of the population of the region are Russians - about $80 \%$. The ethnic communities of Armenians, Ukrainians, and Greeks are traditionally great in the region. In recent decades, the number of Dagestan peoples living in the region, especially Dargins (1.8\%), has increased. Chechens $(0.4 \%)$ live in the east and northeast of the region. In the foothill areas - Karachais (0.6\%), Adyghs $(0.4 \%)$ and Abaza $(0.1 \%)$.

Features of social groups interactions in a multinational region require a unifying factor. As such, the Russian language is a means of interethnic communication. The issue of a meaningful understanding of everyday social practices that occur in different social groups, segmented by sex, age, level of education, type of settlement, is becoming relevant.

The Russian language in the multinational region is characterized by an organizing function in the formation of relations in society, language acts as the basis for mutual understanding, social peace and development. All everyday social practices in various life spheres occur using the language, so the role of Russian as the basis of universal speech communication in the multinational region increases.

In modern society, in the context of globalization and internationalization, the steady growth of international relations, such phenomena as bilingualism and multilingualism of large population groups appear and develop; there is an increase in the role of languages of interethnic communication. People constantly interact with each other in the process of production and consumption, in everyday life and cultural life, during such interaction there 
appears to be a need to talk to one another: to share their life experiences, to exchange news, to evaluate an event, to express their own opinion etc. [1].

Thus, the Russian language is an important means of communication in a multinational region and serves as the basis for positive social practices in the daily life of various groups of the population. And the study of the substantive side of this phenomenon makes it possible to determine the vectors of the national cultural and social policies of the region and the promising areas of education, culture, youth organizations of the Stavropol Region and southern Russia in general, contributing to the development of language communication.

\section{LITERATURE REVIEW}

The communicative function of language is expressed in the fact that language serves as a means of communication between people. Language is realized in speech, which is an external manifestation of the language. A sociological research of the issues of everyday language practices in the North Caucasus and the unifying role of the Russian language is relevant in connection with the need to understand and accept the semantic loads of verbal communication among representatives of different nationalities in a multinational region [8].

The relevance of bilingualism use in everyday social practices of the population is confirmed by active discussion in the scientific community $[10,14,15,16]$.

The study of the influence of bilingualism on the success of solving semantic problems by children who spoke one or two languages was conducted by scientists Spätgens T. and Schoonen R. As a result, it was found that the success of finding the correct answers did not depend on whether the child speaks one or two languages. Monolingual and bilingual children showed similar performance in almost all linguistic indicators [2]. At the same time, the practice of bilingualism helps in the implementation of communications in the multicultural environment of a multinational region.

Authors Lorette P. and Dewaele J.-M. in their scientific publication "The relationship between bi/multilingualism, nativeness, proficiency and multimodal emotion recognition ability", conducted a small number of studies devoted to the research of bilingualism and its influence on the sociopsychological characteristics of a person. In a statistically significant sample, researchers show a bilingual advantage in recognizing emotions (happiness, sadness, anger, surprise, fear, disgust) in English among participants with a specific language profile. Participants who grew up using two languages from birth had an obvious advantage [3]. A similar research approach was used by the authors Adamou E., De Pascale S., García-Márkina Y., Padure C. in the study of bilingualism as a factor that leads to the simplification of language alternatives to reduce cognitive load [4].

The interesting conclusions regarding the multilingual environment and the unifying role of the main language of the territory were made by the authors Lorenz E., Bonnie RJ, Feindt K., Rahbari S., Siemund P. In their opinion, the language of the majority, in this specific study - German, shows a strong influence on both background languages (Russian and Turkish) due to its dominant status [5].

Brouwer S. speaks about the influence of language on moral decision making, depending on whether the action is carried out in the native or non-native language for the participant of the experiment [6]. In general, this study emphasizes the relevance of studying the issue of bilingualism and the use of a non-native language in social and professional practices $[12,13]$.

Thus, a review of publications devoted to linguistic practices in a social environment where not only the native language of the native speaker is used, but also the main (state) one shows, on the one hand, the high relevance of this topic, and on the other, the lack of relevant information [7, 9].

\section{METHODS AND MATERIAL}

The methodological basis of the study was a questionnaire survey of the population of the Stavropol Region. The results of the study have determined the leading role of Russian language in the daily social practices of the population of the Stavropol Region. There is a direct positive correlation between the level of education and the number of everyday practices using Russian as the main communication tool: with an increase in the level of education, the intensity of using Russian in communicating with relatives, friends, and colleagues also increases. Such social groups of the multinational region as women (up to $90 \%$ ), residents of rural district centers and large villages (about 90\%), and older age groups (over 90\%) use the Russian language to a greater extent in everyday life. Thus, emphasizing the leading role of Russian language as an instrument of interethnic communication in a multinational region.

\section{RESULTS}

The majority of respondents $(87.2 \%)$ noted that it is easier to communicate, read, and speak Russian. Thus, the Russian language is widely used for everyday needs not only by those residents of the Stavropol Region who consider themselves Russian by nationality (72.3\% among the survey participants), but also representatives of other nationalities.

TABLE I DISTRIBUTION OF ANSWERS TO THE QUESTION: "WHAT LANGUAGE(S) WOULD YOU LIKE TO MASTER?”, \%

\begin{tabular}{|l|c|}
\hline Answer options & $\%$ \\
\hline 1. English & 52,1 \\
\hline 2. German & 14,2 \\
\hline 3. French & 24,8 \\
\hline 4. Spanish & 15,5 \\
\hline 5. Italian & 17,9 \\
\hline 6. Chinese & 17,0 \\
\hline 7. Japanese & 9,7 \\
\hline 8. Greek & 8,2 \\
\hline 9. Polish & 4,2 \\
\hline 10. Turkish & 7,9 \\
\hline 11. Hebrew (Yiddish) & 5,5 \\
\hline
\end{tabular}


Confirmation that no other language except Russian can fulfill the function of the language of interethnic communication in the territory of the Stavropol Region is the distribution of answers presented in the table 1 .

In the list of languages that the survey participants would like to additionally master there were not the languages of the North Caucasus, Transcaucasia, and the CIS countries. In general, this suggests that the language of interethnic communication - Russian - is enough to solve current issues of life. Among half of the respondents there are those who want to master English, as one of the most common international languages. French $(24.8 \%)$, Italian $(17.9 \%)$, Chinese (17.0\%), Spanish (15.5\%), German (14.2) are also very popular. Other languages were noted by less than $10 \%$ of respondents.

According to the survey, the use of Russian as a communication tool in everyday practices is wider among older age groups - 46 years old and older. Data on the use of Russian in age segmentation is presented in the following table.

TABLE II COMPARATIVE DATA ON THE USE OF RUSSIAN LANGUAGE IN DIFFERENT AGE GROUPS, $\%$

\begin{tabular}{|l|l|l|l|l|l|l|l|}
\hline \multirow{2}{*}{$\begin{array}{l}\text { Answer } \\
\text { options }\end{array}$} & \multicolumn{7}{|c|}{ Age groups } \\
\cline { 2 - 8 } & $\begin{array}{l}18-21 \\
\text { years } \\
\text { old }\end{array}$ & $\begin{array}{l}22-26 \\
\text { years } \\
\text { old }\end{array}$ & $\begin{array}{l}27-35 \\
\text { years } \\
\text { old }\end{array}$ & $\begin{array}{l}36-45 \\
\text { years } \\
\text { old }\end{array}$ & $\begin{array}{l}46-55 \\
\text { years } \\
\text { old }\end{array}$ & $\begin{array}{l}56 \\
\text { years old } \\
\text { and older }\end{array}$ & Total \\
\hline $\begin{array}{l}\text { 1. Not using } \\
\text { Russian, \% }\end{array}$ & 12,7 & 14,7 & 11,4 & 14,3 & 7,7 & - & 12,8 \\
\hline $\begin{array}{l}\text { 2. Using } \\
\text { Russian, \% }\end{array}$ & 87,3 & 85,3 & 88,6 & 85,7 & 92,3 & 100,0 & 87,2 \\
\hline
\end{tabular}

An interesting dependency has also been noted when considering data in the segmentation of respondents by type of settlement (Tab. 03). The wider use of Russian is noted in rural district centers and large rural settlements. Russian is somewhat less demanded in the regional center and cities, where respectively $15.3 \%$ and $12.0 \%$ of respondents in everyday life do not resort to communication in Russian. The same situation is typical for small rural settlements.

TABLE III COMPARATIVE DATA ON THE USE OF RUSSIAN LANGUAGE AMONG REPRESENTATIVES OF DIFFERENT TYPES OF SETTLEMENTS,

\begin{tabular}{|l|r|c|c|c|c|c|}
\hline \multirow{2}{*}{$\begin{array}{c}\text { Answer } \\
\text { options }\end{array}$} & \multicolumn{5}{|c|}{ City/town/locality } & \\
\cline { 2 - 6 } & $\begin{array}{c}\text { Distri } \\
\text { ct } \\
\text { center }\end{array}$ & City & $\begin{array}{c}\text { Rural } \\
\text { district } \\
\text { center }\end{array}$ & $\begin{array}{c}\text { Village, } \\
\text { over } \\
3000 \\
\text { residents }\end{array}$ & $\begin{array}{c}\text { Village, } \\
\text { less than } \\
3000 \\
\text { residents }\end{array}$ & Total \\
\hline $\begin{array}{l}\text { 1. Not } \\
\text { using } \\
\text { Russian, } \\
\%\end{array}$ & 15,3 & 12,0 & 9,8 & 8,7 & 16,7 & 12,8 \\
\hline $\begin{array}{l}\text { 2. Using } \\
\text { Russian, } \\
\%\end{array}$ & 84,7 & 88,0 & 90,2 & 91,3 & 83,3 & 87,2 \\
\hline
\end{tabular}

According to the survey, women are more likely to use Russian in linguistic practices than men (Tab. 04).

TABLE IV COMPARATIVE DATA ON THE USE OF RUSSIAN LANGUAGE BY MEN AND WOMEN WHO PARTICIPATED IN THE SURVEY, \%

\begin{tabular}{|l|c|c|c|}
\hline \multirow{2}{*}{ Answer options } & \multicolumn{2}{|c|}{$\begin{array}{c}\text { Sex of } \\
\text { respondent }\end{array}$} & \multirow{2}{*}{} \\
\cline { 2 - 3 } & Male & Female & Total \\
\hline 1. Not using Russian, \% & 16,9 & 9,3 & 12,8 \\
\hline 2. Using Russian, \% & 83,1 & 90,7 & 87,2 \\
\hline
\end{tabular}

And a fairly clear trend towards an increase in the number of everyday language practices in Russian is noted with an increase in the level of respondents' education. The data is presented in Table V.

TABLE V COMPARATIVE DATA ON THE USE OF RUSSIAN LANGUAGE BY RESPONDENTS WITH DIFFERENT LEVELS OF EDUCATION, \%

\begin{tabular}{|l|c|c|c|c|c|}
\hline \multirow{2}{*}{$\begin{array}{l}\text { Answer } \\
\text { options }\end{array}$} & \multicolumn{4}{|c|}{ Level of education } & \\
\cline { 2 - 5 } & $\begin{array}{l}\text { Incomplete } \\
\text { secondary }\end{array}$ & Secondary & $\begin{array}{l}\text { Specialized } \\
\text { Secondary }\end{array}$ & Higher & Total \\
\hline $\begin{array}{l}\text { 1. Not } \\
\text { using } \\
\text { Russian, } \\
\%\end{array}$ & 17,1 & 17,0 & 13,1 & 11,2 & 12,8 \\
\hline $\begin{array}{l}\text { 2. Using } \\
\text { Russian, } \\
\%\end{array}$ & 82,9 & 83,0 & 86,9 & 88,8 & 87,2 \\
\hline
\end{tabular}

The survey data indicates that about $90 \%$ of respondents with higher education use the Russian language as an instrument of intercultural communication.

Thus, there is a direct positive relationship between the level of education and the number of everyday practices of using the Russian language as the main tool of communication.

\section{DISCUSSION AND CONCLUSIONS}

Summing up the results of our analysis of linguistic social practices in different social groups of the multinational region population, based on a survey in the Stavropol Region, the following can be noted:

- in the scientific discussion various definitions of the language communication issues in multinational regions are discussed, as evidenced by a number of publications dealing with such aspects as the use of bilingualism in different social groups, the role of titular nation language in resolving moral issues, the situation of bilingualism in social and professional practices;

- in a number of studies, there is a lack of empirical data on the role of language in intercultural communication practices in the context of globalization and an increase in everyday social practices of interaction between different nationalities; 
- the results of the study note the leading role of the Russian language in the daily social practices of the population of the Stavropol Region;

- there is a direct positive correlation between the level of education and the number of everyday practices of using Russian as the main tool of communication: with an increase in the level of education, increases the intensity of using Russian in communicating with relatives, friends, and colleagues;

- social groups of the multinational region such as women (up to 90\%), residents of rural district centers and large villages (about 90\%), and older age groups (over 90\%) use Russian to a greater extent in everyday life.

Thus, emphasizing the leading role of the Russian language as an instrument of interethnic communication in a multinational region.

\section{References}

[1] L.P. Pavlova, "Language as a means of communication", in Bulletin of Kurgan State University, vol. 1 (52), pp. 96-98, 2019.

[2] T. Spätgens, R. Schoonen, "Individual differences in reading comprehension in monolingual and bilingual children: The influence of semantic priming during sentence reading", Learning and Individual Differences vol. 76, 101777, 2019.

[3] P. Lorette, J.-M. Dewaele, "The relationship between bi/multilingualism, nativeness, proficiency and multimodal emotion recognition ability" International Journal of Bilingualism, vol. 23(6), pp. 1502-1516, 2019.

[4] E. Adamou, S. De Pascale, Y. García-Márkina, C. Padure, "Do bilinguals generalize estar more than monolinguals and what is the role of conceptual transfer?", International Journal of Bilingualism, vol. 23(6), pp. 1549-1580, 2019.

[5] E. Lorenz, R.J. Bonnie, K. Feindt, S. Rahbari, P. Siemund, "Crosslinguistic influence in unbalanced bilingual heritage speakers on subsequent language acquisition: Evidence from pronominal object placement in ditransitive clauses", International Journal of Bilingualism, vol. 23(6), pp. 1410-1430, 2019.

[6] S. Brouwer, "The auditory foreign-language effect of moral decision making in highly proficient bilinguals", Journal of Multilingual and Multicultural Development, vol. 40(10), pp. 865-878, 2019.

[7] B. O'Rourke, A. Nandi, "New speaker parents as grassroots policy makers in contemporary Galicia: ideologies, management and practices", Language Policy, vol. 18(4), pp. 493-511, 2019.

[8] E.V. Susimenko, G.V. Shevtsova, S.V. Rozhdestvenskaya, E.B Narochnaya, A.A. Popova, "Language policy in multi-ethnic regions as a part of national education: status and trends", On the Horizon, vol. 27(3-4), pp. 219-229, 2019.

[9] S. Heim, J. Stumme, N. Bittner, K. Amunts, S. Caspers, "Bilingualism and "brain reserve": a matter of age", Neurobiology of Aging, vol. 81, pp. 157-165, 2019

[10] E. Akgül, D. Yazıcı, B. Akman, "Views of parents preferring to raise a bilingual child", Early Child Development and Care, vol. 189(10), pp. 1588-1601, 2019

[11] L. Abrahams, R.J. Hartsuiker, F. De Fruyt, M.T. Bajo, "Structural alignment and its prosocial effects in first and second languages", ActaPsychologica, vol. 199, 102906, 2019.

[12] Pérez, J.A. Duñabeitia, "Speech perception in bilingual contexts Neuropsychological impact of mixing languages at the inter-sentential level", Journal of Neurolinguistics, vol. 51, pp. 258-267, 2019.

[13] C.D. Tran, M.M. Arredondo, H. Yoshida, "Early executive function: The influence of culture and bilingualism", Bilingualism, vol. 22(4), pp. 714-732, 2019.

[14] V.A. Ivashova, Y.B. Nadtochy, L.S. Budovich, E.V. Volobuyeva, N.M Volkova, "Motivational field of creative activities of the population of the south of Russia based on the materials of research in the Stavropol Territory", International Journal of Engineering and Technology(UAE), vol. 7 (4), pp. 220-223, 2018

[15] I.S. Baklanov, O.A. Baklanova, A.M. Erokhin, N.N. Ponarina, G.A Akopyan, "Myth as a means of ordering and organizing social reality", Journal of History Culture and Art Research, vol. 7 (2), pp. 41-47, 2018.

[16] V. Ivashova, V. Goncharov, A. Erokhin, O. Kolosova, V. Berkovsky, "Life strategies of graduates of regional universities: the reality of Russian society", International Journal of Civil Engineering and Technology, vol. 9 (13), pp 398-404, 2018. 